\title{
Primary squamous cell carcinoma of the pancreas: a case report and review of the literature
}

\author{
Ravi Kodavatiganti ${ }^{1 *}$, Fiona Campbell ${ }^{1,2}$, Ahmed Hashmi $^{1}$ and Simon W Gollins ${ }^{1}$
}

\begin{abstract}
Introduction: Primary squamous cell carcinoma of the pancreas is a rare tumor with poor prognosis and is found in the literature only as case reports. The optimal management course remains poorly defined. We present a case of primary basaloid squamous cell carcinoma of the pancreas metastatic to the liver, which was treated with surgery and systemic chemotherapy. Our patient survived for 15 months: the longest survival reported in the literature to date.

Case presentation: A 70-year-old Caucasian man presented to hospital with a three-month history of weight loss, pruritus and icterus. Imaging studies confirmed the presence of an operable mass lesion in the head of the pancreas. Following a pancreaticoduodenectomy, histology results led us to make a diagnosis of squamous cell carcinoma. Postoperative restaging showed multiple metastases in the liver. He underwent palliative systemic chemotherapy with cisplatin and 5-fluorouracil achieving partial response and an excellent quality of life. He then went on to start second-line chemotherapy, but unfortunately died of sepsis soon thereafter.
\end{abstract}

Conclusions: This case report emphasizes that achievement of a worthwhile objective and symptomatic palliative response is possible using platinum-based chemotherapy in squamous cell carcinoma of the pancreas.

\section{Introduction}

Squamous cell carcinoma of the pancreas is rare. Squamous cells are not present in the normal pancreas and hence the pathogenesis of this carcinoma remains uncertain. Even though squamous cell carcinomas arising in other parts of the body are considered to be radiosensitive and chemosensitive, and sometimes have better outcomes, the prognosis of squamous cell carcinoma in the pancreas remains poor, as for other pancreatic carcinomas.

\section{Case presentation}

A 70-year-old Caucasian man who was a non-smoker presented to our facility with a three-month history of $12 \mathrm{~kg}$ weight loss and recent generalized itching and jaundice. Serum biochemistry and ultrasound of the abdomen confirmed obstructive jaundice due to a mass in

\footnotetext{
*Correspondence: ravi.kodavatiganti@wales.nhs.uk

${ }^{1}$ North Wales Cancer Treatment Centre, Glan Clwyd Hospital, Sarn Lane, Denbighshire LL18 5UJ, UK

Full list of author information is available at the end of the article
}

the head of the pancreas. The lesion was $4.6 \times 4.1 \mathrm{~cm}$ in size with no evidence of metastatic disease on staging computed tomography (CT) scan. He underwent endoscopic retrograde cholangiopancreatography (ERCP) with a $5 \mathrm{~cm} 10 \mathrm{~F}$ plastic stent inserted into the common bile duct followed by pylorus-sparing pancreaticoduodenectomy two months after diagnosis and recovered uneventfully.

Macroscopically, there was a $5.5 \mathrm{~cm}$ diameter, lobulated tumor within the head of the pancreas extending to the superior mesenteric vessel margin. This entire tumor was sampled for histological examination. Microscopically, the tumor was composed of large nests of basaloid cells with areas of central necrosis (Figure 1) and scattered small foci of squamoid differentiation (Figure 2). There was no evidence of acinar or glandular differentiation morphologically. There was extensive intravenous and intralymphatic invasion, together with foci of perineural invasion. The tumor invaded into the duodenum, around the base of the ampulla, into the pancreatic duct and widely into peripancreatic fat. Tumor involvement

\section{() BioMed Central}




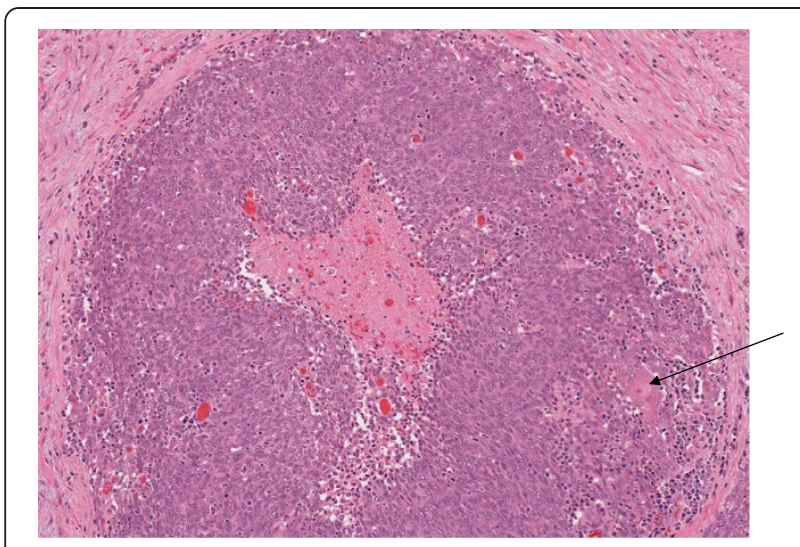

Figure 1 Low power image of the carcinoma with central necrosis and focal squamous differentiation at right edge (arrow).

of the superior mesenteric vessel margin was confirmed microscopically. Metastatic tumor (with similar morphology) was present in six of 43 sampled lymph nodes.

The morphological appearances of the tumor were considered to be those of a poorly differentiated (basaloid) squamous cell carcinoma, which was confirmed with diffuse strong immunostaining with cytokeratin 5/6 and p63. Adenosquamous carcinoma and pancreatoblastoma were considered in the differential diagnosis. Adenosquamous carcinoma is a rare variant of pancreatic ductal adenocarcinoma, showing both glandular differentiation and squamous differentiation. However, no glandular differentiation was seen in our tumor, despite extensive sampling. Pancreatoblastoma occurs in childhood, but rare cases have been described in adults. By definition, it shows acinar differentiation and squamoid nests. However, our tumor showed no acinar growth pattern and no immunostaining with trypsin or $\alpha$-fetoprotein. There were only occasional neuroendocrine cells (immunopositive for synaptophysin and CD56) within the tumor, ruling out a neuroendocrine carcinoma.

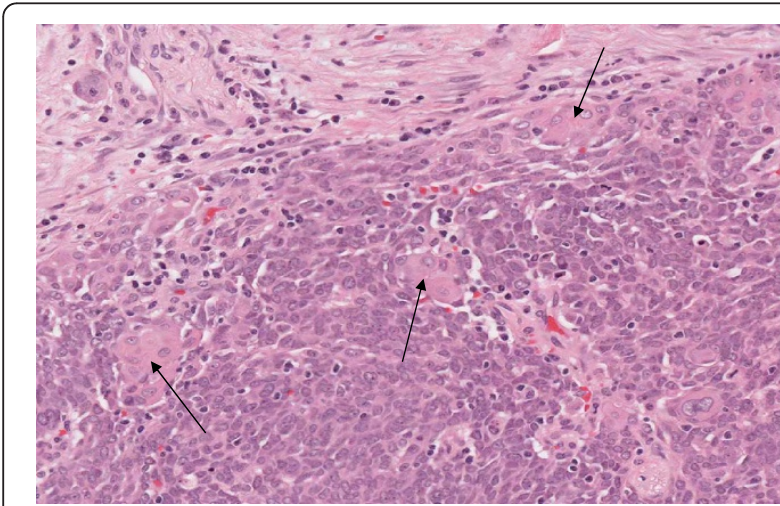

Figure 2 Higher power image with desmoplastic stroma at top and squamous pearls amongst the carcinoma cells (arrows).
Squamous cell carcinoma of the pancreas is extremely rare and, therefore, the possibility was raised that this could be secondary involvement of the pancreas. A repeat staging CT scan was performed postoperatively and revealed possible metastatic spread to the liver, but did not identify any other tumor sites. He underwent an [18F]-2fluoro-2-deoxy-D-glucose (FDG) positron emission tomography-computed tomography (PET-CT) scan one month postoperatively, which was reported to show FDG avid lesions in both lobes of the liver and a solitary FDG avid lymph node anterior to the renal vein. Again, no other occult potential primary site was visible. Two months after surgery, he started systemic palliative chemotherapy with intravenous cisplatin at $80 \mathrm{mg} / \mathrm{m}^{2}$ given on day one and 5fluorouracil $4000 \mathrm{mg} / \mathrm{m}^{2}$ as continuous intravenous infusion over four days (days one to five). On completion of eight three-weekly cycles, restaging CT scan demonstrated what amounted to a partial response in his liver metastases by Response Evaluation Criteria In Solid Tumors (RECIST) scoring. Following this he was then placed on follow-up, achieving an excellent quality of life.

He remained active but developed epigastric pain six months later. A restaging CT scan showed progression in the previously noted metastatic liver disease and a $3.3 \mathrm{~cm}$ mass in the retroperitoneum, suggestive of local recurrence. As he remained active with performance status of 1 on the WHO scale, he commenced second-line chemotherapy with docetaxel a month later. Four days after the first cycle of docetaxel had been administered he was admitted to hospital with sepsis. Blood cultures obtained on admission grew Klebsiella pneumoniae and Clostridium perfringens sensitive to ciprofloxacin, tazocin, gentamicin and metronidazole. Despite treatment with tazocin and gentamicin he died of sepsis within 48 hours of admission.

\section{Discussion}

Primary squamous cell carcinoma of the pancreas is an extremely rare entity with an incidence of $0.5 \%$ to $2 \%$ of all exocrine pancreatic neoplasms [1]. Cases are described in the literature only as case reports [2-11]. In view of its rarity, squamous cell carcinoma (SCC) in the pancreas is presumed to be metastatic from another primary site, until proven otherwise $[1,8]$. However, it should be noted that metastases to the pancreas are also rare. Metastatic spread of primary lung SCC to the pancreas is noted to be common in both surgical and autopsy series with pancreatic involvement usually occurring as part of widespread disease [1]. A case of an isolated metastasis from asymptomatic occult esophageal squamous cell cancer to the pancreas has also been reported to masquerade as primary pancreatic cancer [12].

Our patient was presumed to have operable primary pancreatic cancer. The surprise histological finding of 
squamous cell carcinoma raised the possibility that this may have been a metastatic deposit and a PET-CT scan was thus performed to attempt to localize a possible occult primary. However, the PET-CT scan showed only multiple liver metastases and no other candidate primary site (Figures 3 and 4). Historically, most of the reported cases used CT scans of head, neck and chest, otorhinolaryngological examination and endoscopic examination of the gastrointestinal tract to search for the primary. To the best of our knowledge, this is the only reported case to have used a PET-CT scan to search for the primary in this context.

We undertook a MEDLINE database search to identify cases of pure squamous cell carcinoma of the pancreas reported in the English literature and their management and outcomes using the following key words: carcinoma, squamous cell, pancreas, exocrine, pancreatic neoplasms. Brown et al. in 2005 identified 36 autopsy/registry cases of pure squamous cell carcinoma of the pancreas and 25 cases diagnosed based on ante-mortem histology results [10]. We have identified (Table 1) an additional 14 cases diagnosed ante-mortem since 2005 and a further case diagnosed ante-mortem in 2000 by Fonseca et al. [11], which was not included in the excellent review by Brown et al. [10]. Including the present case, a total of 40 cases of pure squamous cell carcinoma of the pancreas, diagnosed based on histology findings, have been reported in the English literature.

The normal pancreas is devoid of squamous cells and the origin of pancreatic SCC is uncertain. Various

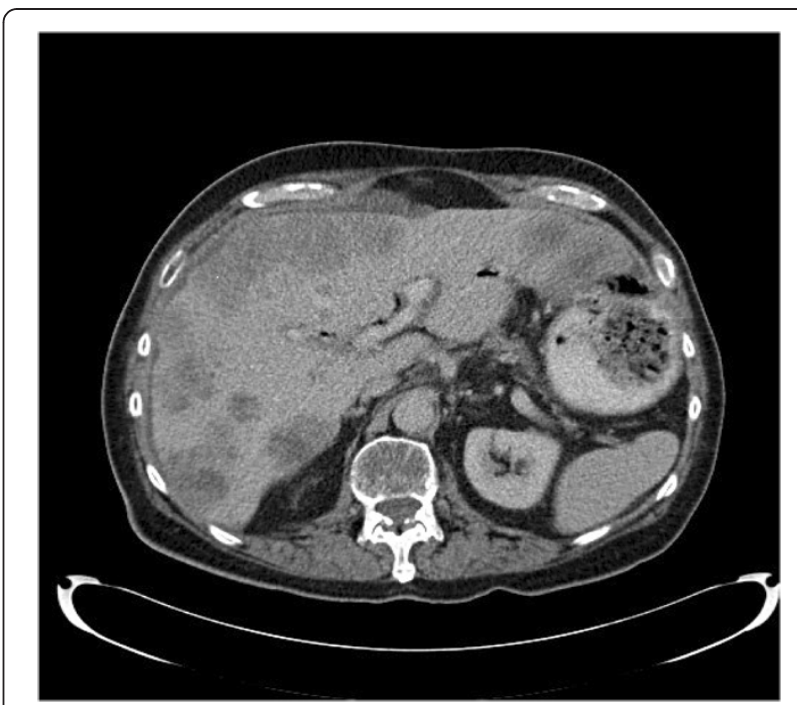

Figure 4 Computed tomography scan showing multiple liver metastases prior to second-line palliative chemotherapy.

mechanisms postulated for evolution of pure squamous cell carcinoma include malignant transformation of squamous metaplasia, squamous metaplastic change in a pre-existing adenocarcinoma, and differentiation with malignant transformation of primitive multipotent cells [1]. Squamous metaplasia occurs in chronic pancreatitis and following pancreatic/biliary stents. However, our patient had no previous episodes of pancreatitis and the stent was only inserted pre-operatively.

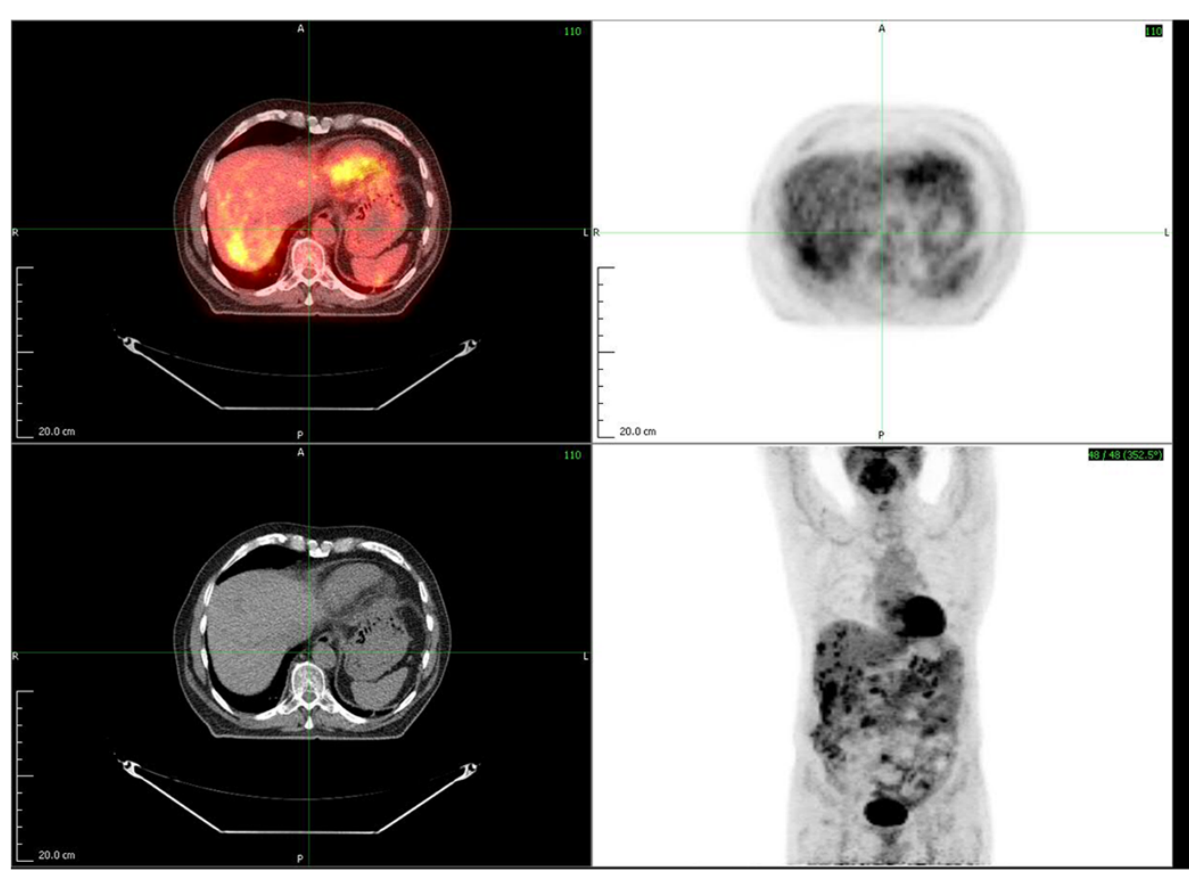

Figure 3 Positron emission tomography-computed tomography scan showing multiple liver metastasis immediately postpancreaticoduodenectomy and prior to first-line palliative chemotherapy. 
Table 1 Reported cases of squamous cell carcinoma of the pancreas in the literature

\begin{tabular}{|c|c|c|c|c|c|c|c|c|c|c|c|c|}
\hline Author/reference & $\begin{array}{c}\text { Year of } \\
\text { publication }\end{array}$ & $\begin{array}{l}\text { No. of patients } \\
\text { reported }\end{array}$ & Age & Sex & Race & $\begin{array}{l}\text { Presenting } \\
\text { symptom(s) }\end{array}$ & Location & Size & Surgery & Outcome & Treatment & $\begin{array}{c}\text { Time to death } \\
\text { (months) }\end{array}$ \\
\hline Kensuke [2] & 2011 & 1 & 67 & $F$ & Japanese & Anorexia, back pain & Tail & $6 \mathrm{~cm}$ & $\begin{array}{l}\text { Distal panreatectomy, } \\
\text { total gastrectomy, } \\
\text { splenectomy. }\end{array}$ & $\begin{array}{l}L R \text { at } \\
\text { four months }\end{array}$ & $\begin{array}{l}\text { Radiotherapy } \\
\quad \text { for LR }\end{array}$ & $\begin{array}{l}11 \text { months } \\
\text { from S }\end{array}$ \\
\hline Mansfield et al. [3] & 2010 & 8 & 64 (median) & $6 \mathrm{M}+2 \mathrm{~F}$ & NA & $\begin{array}{c}\text { Jaundice }(4 / 8) \text {, } \\
\text { abdominal } \\
\text { discomfort }(3 / 8), \\
\text { back pain }(1 / 8), \text { early } \\
\text { satiety }(1 / 8)\end{array}$ & NA & NA & $\begin{array}{c}1(S), 1(S+R), 3(S+R+C) \\
1(C), 2(P)\end{array}$ & NA & NA & $\begin{array}{l}\text { Median five } \\
\text { months }\end{array}$ \\
\hline Terada [4] & 2010 & 1 & 69 & $\mathrm{~F}$ & Japanese & $\begin{array}{c}\text { Abdominal } \\
\text { pain, jaundice }\end{array}$ & Head & $5 \mathrm{~cm}$ & $\begin{array}{l}\text { Pancreaticoduodenect- } \\
\text { omy }\end{array}$ & Distant metastasis & Nil & $\begin{array}{l}\text { Three } \\
\text { months }\end{array}$ \\
\hline Lai et al. [5] & 2009 & 1 & 76 & $\mathrm{~F}$ & $\begin{array}{l}\text { African- } \\
\text { American }\end{array}$ & $\begin{array}{l}\text { Epigastric/back pain, } \\
\text { weight loss }\end{array}$ & Tail & $5 \mathrm{~cm}$ & $\begin{array}{c}\text { Cytological diagnosis, } \\
\text { no histology }\end{array}$ & $\begin{array}{l}\text { Liver metastasis } \\
\text { at diagnosis }\end{array}$ & Not known & Not known \\
\hline Rana et al. [6] & 2009 & 1 & 50 & M & NA & $\begin{array}{l}\text { Abdominal pain, } \\
\text { jaundice, } \\
\text { weight loss }\end{array}$ & Head & NA & $\begin{array}{c}\text { No surgery, cytological } \\
\text { diagnosis, } \\
\text { no histology }\end{array}$ & $\begin{array}{l}\text { Peritoneal deposits, } \\
\text { ascites at diagnosis }\end{array}$ & Nil & Not known \\
\hline Qiang-pu et al. [7] & 2008 & 1 & 55 & M & $\begin{array}{l}\text { Mandarin } \\
\text { Chinese }\end{array}$ & $\begin{array}{l}\text { Jaundice, } \\
\text { weight loss }\end{array}$ & Head & $4 \mathrm{~cm}$ & $\begin{array}{l}\text { Pancreaticoduodenect- } \\
\text { omy and segmental } \\
\text { liver resection }\end{array}$ & $\begin{array}{l}\text { Liver metastasis } \\
\text { at } 10 \text { months }\end{array}$ & Nil & 10 months \\
\hline Al-Shehri et al. [8] & 2008 & 1 & 48 & $\mathrm{~F}$ & NA & $\begin{array}{l}\text { Abdominal pain, } \\
\text { jaundice, } \\
\text { weight loss }\end{array}$ & Head & $4.4 \mathrm{~cm}$ & Palliative bypass surgery & $\begin{array}{l}\text { Liver metastasis } \\
\text { at diagnosis }\end{array}$ & $\begin{array}{l}\text { Carboplatin+ } \\
\text { gemcitabine } \\
\text { (two courses) }\end{array}$ & $\begin{array}{l}\text { Five months } \\
\text { OS from } \\
\text { presentation }\end{array}$ \\
\hline $\begin{array}{l}\text { Anagnostopoulos } \\
\text { et al. [9] }\end{array}$ & 2006 & 1 & 72 & M & NA & Painless jaundice & Head & $6 \mathrm{~cm}$ & Palliative bypass surgery & & Nil & Four months \\
\hline Brown et al. [10] & 2005 & $\begin{array}{l}1 \text { (plus } 24 \\
\text { case literature } \\
\text { review) }\end{array}$ & & & & & & & $\begin{array}{l}\text { published } \\
\text { literature }\end{array}$ & & & \\
\hline Fonseca et al. [11] & 2000 & 1 & 52 & M & NA & Melena, jaundice & Head & NA & $\begin{array}{c}\text { No surgery, cytological } \\
\text { diagnosis, } \\
\text { confirmed histology } \\
\text { at autopsy }\end{array}$ & $\begin{array}{l}\text { Liver metastasis } \\
\text { at diagnosis }\end{array}$ & Nil & 712 days \\
\hline
\end{tabular}

Abbreviations: S Surgery, $R$ Radiotherapy, $C$ Chemotherapy, $P$ Palliative care, $L R$ Local relapse, OS Overall survival, NA Not available. 
Surgery still remains the corner stone in the management of this rare cancer as for the much more common ductal adenocarcinoma of the pancreas. Median survival for pancreatic SCC was noted to be seven months, with a range of six to 16 months, in the seven patients who underwent curative resection [10]. In our literature search we identified three patients whose overall survival was three, 10 and 11 months following curative resection [2,4,7]. We could not establish the overall survival of the fourth patient who had curative resection from the Mayo clinic series [3]. Median survival for those who did not have curative resection was three months (range onequarter of a month to nine months) [3,10]. A total of 17 out of 39 patients had treatment for locally advanced, recurrent or metastatic squamous cell cancer of pancreas. The treatment included systemic chemotherapy and/or radiotherapy. Cisplatin was used in combinations with fluorouracil (three patients) [10,13], etoposide (one patient) [10] and vinblastine (one patient) [10]. Gemcitabine was used in combination with carboplatin (one patient) [8] and fluorouracil (one patient) [10]. The survival in these patients was poor except for one patient who recurred locally after surgery at four months. He received local radiotherapy and had an overall survival of 11 months.

Even though our patient relapsed early after surgery with multiple liver metastases, he appears to have benefited considerably from palliative systemic chemotherapy. He achieved an overall survival of 15 months from the surgery. He tolerated chemotherapy well and had a good quality of life during chemotherapy and for the majority of the seven months between completing chemotherapy and his presentation with symptomatic relapse. We elected to treat our patient with a platinumbased systemic chemotherapy regimen as it is active and used in various combinations for treatment of squamous cell carcinomas arising at different sites including lung, head and neck, cervix and skin.

\section{Conclusions}

Pure primary squamous cell carcinoma of the pancreas is a rare carcinoma and, therefore, spread from other primary squamous cell cancers should always be considered and carefully excluded. Surgery remains the corner stone of treatment but unfortunately is not curative with the clinical course complicated by local and/or distant relapses. This current case report emphasizes that achievement of a worthwhile objective and symptomatic palliative response is possible using platinum-based chemotherapy in squamous cell carcinoma of the pancreas. The treatment of these rare cancers is challenging and may only be improved by centralized national registries.

\section{Consent}

Written informed consent was obtained from the patient's next of kin for publication of this case report and any accompanying images. A copy of the written consent is available for review by the Editor-in-Chief of this journal.

\section{Competing interests \\ The authors declare that they have no competing interests.}

\section{Authors' contributions}

RK assessed our patient on presentation following surgery, arranged restaging investigations, planning of systemic chemotherapy, supervision of treatment and writing of the case report. FC reported the histopathology findings, provided the microphotographs and contributed to the writing of the case report. AH was involved in the literature search and writing up the case report. SWG was the supervising consultant in charge of patient management and helped in writing the manuscript. All authors read and approved the final manuscript.

\section{Author details}

${ }^{1}$ North Wales Cancer Treatment Centre, Glan Clwyd Hospital, Sarn Lane, Denbighshire LL18 5UJ, UK. ²Department of Histopathology, The Royal Liverpool and Broadgreen University Hospitals NHS trust, Prescot street, Liverpool L7 8XP, UK.

Received: 21 February 2012 Accepted: 23 July 2012

Published: 13 September 2012

\section{References}

1. Bixler HA, Castro MJ, Stewart J III: Cytologic differentiation of squamous elements in the pancreas. Diagn Cytopathol 2011, 39:539-540.

2. Adachi K: Primary squamous cell carcinoma of the pancreas: a case report. J Pancreas 2011, 12:181-184.

3. Mansfield A, Tafur A, Smithedajkul P, Corsini M, Quevedo F, Miller R: Mayo clinic experience with very rare exocrine pancreatic neoplasms. Pancreas 2010, 39:972-975.

4. Terada T: Adenosquamous carcinoma and pure squamous cell carcinoma of the pancreas: report of two cases. Case Rep Gastroenterol 2010, 4:369-373.

5. Lai LH, Romagnuolo J, Adams D, Yang J: Primary squamous cell carcinoma of pancreas diagnosed by EUS-FNA: a case report. World J Gastroenterol 2009, 15:4343-4345.

6. Rana SS, Bhasin DK, Jain K, Nada R, Sinha SK, Singh K: Endoscopic diagnosis of squamous cell carcinoma of the pancreas invading the stomach. J Pancreas 2009, 10:181-183.

7. Qiang-pu C, Kun O, Qing-Hai G, Fan Z: Squamous cell carcinoma of the pancreas with liver metastasis: a case report. Chin Med J 2008, 121:853-854.

8. Al-Shehri A, Silverman S, King KM: Squamous cell carcinoma of the pancreas. Curr Oncol 2008, 15:293-297.

9. Anagnostopoulos GK, Aithal GP, Ragunath K, Kaye P, Rowlands BL: Squamous cell carcinoma of the pancreas: report of a case and review of the literature. J Pancreas 2006, 7:47-50.

10. Brown HA, Dotto J, Robert M, Salem RR: Squamous cell carcinoma of the pancreas. J Clin Gastroenterol 2005, 39:915-919.

11. Fonseca J, Brito MJ, Castro C, Lopes L, Folgado A, Murinello F, Leal C: Pancreatic squamous cell carcinoma mimicking a bleeding duodenal ulcer. Gastrointest Endosc 2000, 51:362-363.

12. Kolbusz R, Reyes C, Hakky M, Gradini R: Asymptomatic oesophageal squamous cell carcinoma masquerading as rare primary pancreatic carcinoma. Diagnosis by fine needle aspiration. Acta Cytol 1988, 32:399-402.

13. Itani KMF, Karni A, Green L: Squamous cell carcinoma of the pancreas. J Gastrointest Surg 1999, 3:512-515.

doi:10.1186/1752-1947-6-295

Cite this article as: Kodavatiganti et al:: Primary squamous cell carcinoma of the pancreas: a case report and review of the literature. Journal of Medical Case Reports 2012 6:295 